\title{
Acinetobacter calcoaceticus-baumannii Complex Strains Induce Caspase-Dependent and Caspase-Independent Death of Human Epithelial Cells
}

\author{
Sylwia Krzymińska • Hanna Frąckowiak • \\ Adam Kaznowski
}

Received: 29 February 2012/ Accepted: 15 May 2012/Published online: 9 June 2012

(C) The Author(s) 2012. This article is published with open access at Springerlink.com

\begin{abstract}
We investigated interactions of human isolates of Acinetobacter calcoaceticus-baumannii complex strains with epithelial cells. The results showed that bacterial contact with the cells as well as adhesion and invasion were required for induction of cytotoxicity. The infected cells revealed hallmarks of apoptosis characterized by cell shrinking, condensed chromatin, and internucleosomal fragmentation of nuclear DNA. The highest apoptotic index was observed for 4 of $10 \mathrm{~A}$. calcoaceticus and 4 of 7 A. baumannii strains. Moreover, we observed oncotic changes: cellular swelling and blebbing, noncondensed chromatin, and the absence of DNA fragmentation. The highest oncotic index was observed in cells infected with 6 A. calcoaceticus isolates. Cell-contact cytotoxicity and cell death were not inhibited by the pan-caspase inhibitor $\mathrm{z}$-VAD-fmk. Induction of oncosis was correlated with increased invasive ability of the strains. We demonstrated that the mitochondria of infected cells undergo structural and functional alterations which can lead to cell death. Infected apoptotic and oncotic cells exhibited loss of mitochondrial transmembrane potential $\left(\Delta \Psi_{\mathrm{m}}\right)$. Bacterial infection caused generation of nitric oxide and reactive oxygen species. This study indicated that Acinetobacter spp. induced strain-dependent distinct types of epithelial cell death that may contribute to the pathogenesis of bacterial infection.
\end{abstract}

S. Krzymińska $(\bowtie) \cdot$ H. Frąckowiak · A. Kaznowski Department of Microbiology, Faculty of Biology, Adam Mickiewicz University, ul. Umultowska 89, 61-614 Poznan, Poland

e-mail: sylkrzym@amu.edu.pl

\section{Introduction}

Bacteria of the genus Acinetobacter are widespread in nature. Some of them are a part of human skin flora and are important opportunistic pathogens that cause hospitalacquired infections $[25,30]$. The prevalence ranges from 2 to $10 \%$ of all Gram-negative bacterial infections in Europe [23]. The genus currently contains 33 named and unnamed genomic species. A. baumannii, A. calcoaceticus, unnamed genospecies 3 and $13 \mathrm{TU}$ are genotypically closely related and phenotypically difficult to distinguish. For this reason, it has been proposed to group those species as Acinetobacter calcoaceticus-baumannii complex (Acb) [30]. They include species with the highest prevalence in clinical specimens $[14,30,37]$. They are most commonly associated with hospital-acquired infections and they account for about $75 \%$ of Acinetobacter spp. isolated from clinical specimens. The isolates are usually multiresistant, requiring complicated therapy. The strains are responsible for nosocomial bacteremia, hospital and community-acquired pneumonia, endocarditis, skin, soft tissue, and urinary infections [18, 30, 33]. Many infections can be severe with mortality rates from 26 to $70 \%$ [30].

Although the bacteria are associated with increased hospital outbreaks, little is known about their virulence factors. Outer membrane proteins of Acinetobacter spp. (OmpA) and lipopolysaccharide (LPS) could play an important role in its pathogenicity, resulting in lethality for mice and cytotoxicity of phagocytic and epithelial cells $[6,18]$. Choi et al. [6, 7] have suggested that OmpA of Acinetobacter baumannii (AbOmp) is responsible for adherence, invasion of epithelial cells during the colonization. They have also suggested that the protein induces cytotoxicity and apoptosis of epithelial cells through cell surface death receptors and caspases activation. LPS is 
involved in a strong inflammatory response, production of cytokines and tumor necrosis factor alpha [30].

Many bacterial pathogens have developed specific strategies to suppress the effective antimicrobial response of non-phagocytic cells to avoid the host innate immune defence. The ability of bacterial pathogens to promote host cell death may be important for bacterial survival, escape from the host defence and is implicated in the mechanism of pathogenesis of a variety of infectious diseases [24, 25]. Apoptosis is a form of programmed cell death regulated by cellular signaling cascades that avoid eliciting inflammation [11]. Based on morphological criteria, cell death associated with cellular and organelles swelling and blebbing has been termed as oncosis. Necrosis is the final stage of cellular disintegration which leads to cell lysis [25, 27, 36].

The mechanism of the Acb complex strains pathogenesis has not been clearly defined. During host infection, epithelial cells are the first that the bacteria interact with. Therefore, we focused on the interaction of Acb with the cells. We chose HEp-2 cells as a well established and frequently used in vitro model for studying interactions of bacteria and human cells [12]. We determined the relationship between adhesion and invasion of epithelial cells, cytotoxic activity, production of nitric oxide (NO) and reactive oxygen species (ROS), and cell death induced during bacterial infection.

\section{Materials and Methods}

\section{Bacterial Strains}

Seventeen Acb strains were isolated from various specimens (wounds, aspirates, urine, catheter, sputum, abdominal cavity fluid) of hospitalized patients of intensive care units, between February 2006 and October 2010 (Table 1). They were identified with the API 20 NE system (bioMérieux). They were grown in trypticase soy broth (TSB, Difco) or agar (TSA). The strains were maintained at $-75{ }^{\circ} \mathrm{C}$ in TSB containing $50 \%$ (v/v) glycerol. All strains were gentamicin-sensitive with MIC below $50 \mu \mathrm{g} / \mathrm{ml}$. A non-pathogenic Escherichia coli K-12 C600 strain was used as the negative control.

\section{Epithelial cell line}

Human laryngeal epithelial cells, HEp-2 were cultured in Eagle minimum essential medium (GM, Sigma) supplemented with $2 \mathrm{mM}$ glutamine, $1000 \mathrm{IU} / \mathrm{ml}$ of penicillin G, $100 \mu \mathrm{g} / \mathrm{ml}$ of streptomicin, $1 \mathrm{mg} / \mathrm{ml}$ of nystatin, and $5 \%$ fetal calf serum (FCS, Sigma) The cells were seeded with $100 \mu \mathrm{l}$ of suspension in number $2 \times 10^{5}$ cells per well and incubated at $37{ }^{\circ} \mathrm{C}$ in the atmosphere with $5 \% \mathrm{CO}_{2}$ [21].
Table 1 Species of Acb complex used in the study

\begin{tabular}{lll}
\hline $\begin{array}{l}\text { Acinetobacter species } \\
\text { (Number of strains) }\end{array}$ & Source of origin & Strain No \\
\hline A. calcoaceticus (10) & Secretion & MPU M5, 9, 12, 13, 17 \\
& Urine & MPU M6, 7, 8, 19 \\
& Medical device & MPU M4 \\
A. baumannii (7) & Urine & MPU M16 \\
& Wound & MPU M21 \\
& Medical device & MPU M22, 24 \\
& Secretion & MPU M20, 23, 25 \\
\hline
\end{tabular}

MPU M-collection of Acinetobacter spp. strains in the Department of Microbiology Adam Mickiewicz University in Poland

Infection Conditions

A monolayer of HEp-2 cells with FCS was infected with bacteria cells at the multiplicity of infection (MOI) of 100 for $90 \mathrm{~min}$ at $37{ }^{\circ} \mathrm{C}$. Then the cells were washed twice with PBS and incubated with GM containing $200 \mu \mathrm{g} / \mathrm{ml}$ of gentamicin for $2 \mathrm{~h}$ to kill extracellular bacteria. Then the infected monolayer was incubated with GM without antibiotics for 24 and $48 \mathrm{~h}$ [7].

\section{Acinetobacter spp. Adhesion and Invasion of HEp-2} Cells

Bacterial adhesion and invasion were quantified using gentamicin protection assay [21, 22] with modifications. Epithelial cells grown in 6-well plates (Nunc) were infected with the bacteria at the MOI of 100 for $2 \mathrm{~h}$. The HEp-2 monolayer where the invasion was studied was incubated with GM containing $200 \mu \mathrm{g} / \mathrm{ml}$ of gentamicin for $2 \mathrm{~h}$ at $37{ }^{\circ} \mathrm{C}$ to kill extracellular bacteria. The cells where the invasion and adhesion were studied were incubated with GM without the antibiotic for $2 \mathrm{~h}$. Next, the cells were washed three times with PBS and lysed with the medium containing $0.01 \mathrm{M} \mathrm{NaH} \mathrm{PO}_{4}, 0.1 \%$ Tween 20 (v/v), $0.025 \%$ trypsin $(\mathrm{w} / \mathrm{v}) \mathrm{pH} 8.0$ for $30 \mathrm{~min}$. The total number of cell-associated bacteria (intracellular plus surfaceadherent) and the intracellular bacteria was determined by plating tenfold serial dilutions of the lysate onto TSA. The number of attached bacteria was determined by subtracting the number of intracellular bacteria following the invasion from the total number. The results were expressed as the adhesion index (AdI), i.e., the mean total number of colony-forming units (CFU) associated bacteria per well $\left(2 \times 10^{5} \mathrm{HEp}-2\right.$ cells $)$. Invasion activity was expressed as the invasion index (InI) as the percentage of bacteria after gentamicin treatment in comparison to the number of those associated. The monolayer was infected separately with an invasive strain of Yersinia enterocolitica $0: 8 / 1 \mathrm{~B}\left(\mathrm{pYV}^{+}\right)$ and non-pathogenic $E$. coli K-12 C600. To inhibit bacterial 
internalization, HEp-2 cells were treated with cytochalasin $\mathrm{D}(1 \mu \mathrm{g} / \mathrm{ml})($ Sigma) $1 \mathrm{~h}$ prior to infection.

\section{Cytotoxicity Assay}

For preparing bacterial filtrates, overnight cultures in LB were incubated in TSB in a shaking incubator with agitation at $300 \mathrm{rpm}$ at $37{ }^{\circ} \mathrm{C}$ for $18 \mathrm{~h}$. The supernatants were centrifuged at $3,000 \times g$ for $20 \mathrm{~min}$ and sterilized through $0.22-\mu \mathrm{m}$ pore size membrane filters Millex-GV (Millipore). Twofold serial dilutions (from 1:2 to 1:512) of culture filtrates in phosphate buffered saline (PBS, Biomed) added to the wells of tissue culture plate containing confluent HEp-2 monolayer and incubated for $24 \mathrm{~h}$ at $37{ }^{\circ} \mathrm{C}$. As negative controls, the wells received non-pathogenic E. coli K-12 C600 filtrate and GM. The cytotoxic titer of each isolate was calculated by determining the reciprocal of the highest dilution of the culture filtrates which produced cytopathic effect [22]. The results were observed under an inverted microscope.

\section{Cell-Contact Cytotoxicity}

To determine whether cell contact is required for Acb cytotoxicity, we used trans-well system plates with tissue culture inserts (Nunc) with the anopore membrane with pore diameter of $0.2 \mu \mathrm{m}$. HEp-2 cells were cultured in the lower chamber. Following this, the bacterial cells at MOI of 100 were added in the upper chamber and incubated for $5 \mathrm{~h}$. The cytotoxicity was measured by means of the mitochondrial-dependent reduction of colorless [3-(4,5dimethylthiazol-2-yl)-2,5diphenyltetrazolium bromide] (MTT, Sigma) to a blue formazan, as described previously by Krzymińska et al. [20].

\section{Assessment of apoptosis}

Infected HEp-2 cells were stained with acridine orange (AO) and ethidium bromide (EtBr) [31]. The monolayer was detached using $0.25 \%$ trypsin and $0.25 \%$ EDTA in PBS, and the suspension was stained with AO $(100 \mu \mathrm{g} / \mathrm{ml})$ and $\operatorname{EtBr}(100 \mu \mathrm{g} / \mathrm{ml})$ solution, and examined under the fluorescence microscope (Nikon Eclipse TE-2000). The percentage of apoptotic and necrotic cells represented as apoptotic (ApI) and necrotic indexes were determined by counting a minimum of 100 cells selected at random from three preparations [21]. In positive controls, the HEp-2 cell monolayer was UV-B-irradiated $\left(180 \mathrm{~J} / \mathrm{m}^{2}\right)$.

\section{Transmission Electron Microscopy (TEM)}

Electron microscopy was used to evaluate morphological changes in HEp-2 cells. Infected cells after 24 and $48 \mathrm{~h}$ were washed three times with PBS and harvested using trypsin $(500 \mathrm{mg} / \mathrm{ml})$ and EDTA $(200 \mathrm{mg} / \mathrm{ml})$ solutions. The cells were centrifuged at $1,500 \times g$ for $15 \mathrm{~min}$, fixed with $2.5 \%$ glutaraldehyde in $0.1 \mathrm{M}$ phosphate buffer $(\mathrm{pH}$ 7.2) for $1 \mathrm{~h}$, washed with phosphate buffer, postfixed with $1 \% \mathrm{OsO}_{4}$, gradually dehydrated in series of acetone, and embedded in Epon [7]. The samples were sliced into 70-nm sections, stained with uranyl acetate and examined with transmission electron microscope (JEM 1200 EXII) TEM at accelerating voltage of $80 \mathrm{kV}$.

\section{DNA Fragmentation Assay}

To determine DNA fragmentation, as a biochemical marker of apoptosis, the nucleic acid was extracted from infected epithelial cells, as described previously [21].

\section{Confocal Microscopy Imaging of Mitochondrial} Transmembrane Potential

To assess the effect of Acb-infection on mitochondrial transmembrane potential $\left(\Delta \Psi_{\mathrm{m}}\right)$, we used potentiometric dye tetramethylrhodamine ethyl (TMRE, Sigma). TMRE fluorescence (excitation $568 \mathrm{~nm}$, emission $>590 \mathrm{~nm}$ ) was visualized on a confocal laser scanning microscope equipped with a krypton-argon laser, using a Plan Apo oilimmersion objective (Nikon). In the assay, the fluorescent dye TMRE binds to mitochondria with high $\Delta \Psi$ and the dye is released from the mitochondria when $\Delta \Psi_{\mathrm{m}}$ dissipates $[1,3]$. We determined the fluorescence intensity at a single cell level [4]. The results were expressed in fluorescence units (FU). The average pixel intensity for each cell and the percentage of cells that exhibited a reduced level of fluorescence were assessed.

\section{Caspase Inhibition Assay}

To determine the possible involvement of caspases in Acbinduced cell death, the HEp-2 monolayer was pretreated with the pan-caspase inhibitor z-VAD-fmk (R\&D Systems) for $1 \mathrm{~h}$ prior to the infection with the bacteria, and the inhibitor was present throughout the experiment. After $24 \mathrm{~h}$, estimation of the apoptotic and oncotic indexes in cells after staining with $\mathrm{AO}$ and $\mathrm{EtBr}$ and estimation of $\Delta \Psi_{\mathrm{m}}$ potential revealed by TMRE fluorescence were determined.

Measurement of NO production in infected epithelial cells

$\mathrm{NO}$ is rapidly converted to a stable end product, nitrite $\left(\mathrm{NO}_{2}{ }^{-}\right)$whose concentration in culture supernatants was quantitated using the Griess reaction [10]. 
To inhibit NO production, $10 \mathrm{nM}$ aminoguanidine (AG, Sigma), a structural analog of L-arginine, an inhibitor of inducible NO synthase (iNOS) was used [29]. A monolayer of HEp-2 cells was also incubated for $24 \mathrm{~h}$ with $30 \mu \mathrm{M}$ tocopherol (Sigma), as an antioxidant. The culture medium was removed and the cells were exposed to Acinetobacter spp. The inhibitor and antioxidant were included in the medium throughout the experiment and mitochondrial membrane potential of infected cells was determined.

\section{Statistical analysis}

The data were presented as mean \pm standard deviation from two independent experiments performed in duplicate. A one-way analysis of variance ANOVA with Tukey's post hoc test at the significance level $P<0.05$ was performed. Pairwise correlations between the apoptotic index and cytotoxicity, adhesion, $\Delta \Psi_{\mathrm{m}}$, and $\mathrm{NO}$, were analyzed using the bivariate linear regression model. The Pearson's correlation coefficient was calculated. Values at $P<0.05$ were considered as statistically significant. The statistical analysis was performed using Statistica PL software (StatSoft Inc.).

\section{Results and Discussion}

Acinetobacter spp. Adhesion and Invasion of Epithelial Cells

Quantitative determination of adhesion and invasion of epithelial cells by Acb strains was assessed by gentamicin protection assay. All strains revealed higher adhesion ability to the cells than non-invasive $E$. coli $\mathrm{K}-12 \mathrm{C} 600$ and invasive $Y$. enterocolitica $\mathrm{O}: 8 / 1 \mathrm{~B}$ controls (Table 2). The number of bacteria adhered to the cells was between $17.7 \times 10^{5}$ and $28.5 \times 10^{5} \mathrm{CFU}$. The non-pathogenic E. coli K-12 C600 showed AdI $6.1 \times 10^{5} \mathrm{CFU}$, whereas that of $Y$. enterocolitica $\mathrm{O}: 8 / 1 \mathrm{~B}$ positive control was equal to $17.6 \times 10^{5} \mathrm{CFU}$. The highest adhesion indexes, from $21.4 \times 10^{5}$ to $28.5 \times$ $10^{5} \mathrm{CFU}$, exhibited five (50\%) A. calcoaceticus and five (71\%) A. baumannii strains.

The results could be an explanation for the prevalence of Acb strains on the epithelium which is the most frequent colonization and infection site. The interaction of the bacteria with epithelial cells is the first stage of successive bacterial invasion of the host [28]. Gohl et al. [13] have suggested that thin pili of Acinetobacter sp. strains mediate in biofilm formation and are involved in adhesion to biotic and abiotic surfaces.

To assess the ability of an Acb to invade epithelial cells, the monolayer was infected with the bacteria and the number of intracellular was estimated. The percentage of associated bacteria that were internalized ranged from 0.07 to $61.2 \%$ (Table 2). The invasion index of $Y$. enterocolitica $0: 8 / 1 \mathrm{~B}$ reached $64.1 \%$. Four (40\%) A. calcoaceticus and two (29\%) A. baumannii strains revealed the highest invasion ability comparable to that of the invasive control. Two $(20 \%)$ A. calcoaceticus and two (29\%) A. baumannii strains showed the lowest invasive ability, as that of nonpathogenic negative control. The invasion index for $E$. coli K-12 C600 strain that invaded HEp-2 cells was $0.07 \%$ of total adhered cells. The treatment of epithelial cells with cytochalasin D had no effect on Acinetobacter spp. adhesion but resulted in reduction of the bacteria uptake in the range from $89 \%( \pm 4.1 \%)$ to $93 \%( \pm 3.9 \%)$ after $24 \mathrm{~h}$. Cytochalasin D did not affect HEp-2 cell viability.

A prerequisite for infection is the encounter between pathogenic bacteria and the host tissue. Therefore, the ability to adhere and invade host cells is important virulence factors. Choi et al. [7] have suggested that outer membrane protein A (OmpA) produced by A. baumannii strains is responsible for adherence to and invasion of epithelial cells. Moreover, A. baumannii strains produce phospholipase D (PLD) that could be a potent virulence factor that modulates bacterial invasion of epithelial cells and enhances pathogenesis in the murine model of pneumonia [15].

\section{Extracellular Cytotoxic Activity}

Cell-free supernatants of $10(59 \%)$ Acb strains were cytotoxic to epithelial cells after 24-h incubation (Table 2). The cytopathic effect caused by the activity of extracellular toxins was detected by rounding and shrinkage of the cells and destruction of the monolayer. The highest titer, amounting to 32 , was observed for two $(20 \%)$ A. calcoaceticus and one (14\%) A. baumannii, the lowest one (from 8 to 1) noted for three (30\%) A. calcoaceticus and four (57\%) A. baumannii isolates. The supernatants of seven $(41 \%)$ strains and $E$. coli K-12 C600, which was the negative control, were not cytotoxic to epithelial cells.

Toxin production by Acb strains is still not clearly defined. It has been demonstrated that the most potent extracellular virulence factor produced by $A$. baumannii strains is outer membrane protein A (AbOmpA) $[6,7]$. It is a porin that allows for a passing of small particles in the outer membrane and induce cytotoxicity of host cells. Jin et al. [17] identified A. baumannii outer membrane vesiclemediated delivery of AbOmpA to host cells, after which the proteins induced cytotoxicity. Some Acinetobacter spp. strains produce a capsule composed of rhamnose, glucose, mannose, and glucuronic acid [18]. Exopolysaccharide production by pathogenic bacteria is the major virulence factor that protects the bacteria from host defences, resulting in cytotoxicity for phagocytic cells. Joly-Guillou 
Table 2 Apoptotic (ApI), oncotic (OI) indexes of HEp-2 cells infected with Acb complex strains at 24 and $48 \mathrm{~h}$ with and without the pancaspase inhibitor, extracellular and cell-contact cytotoxicity, adhesion (AdI), and invasion (InI) indexes

\begin{tabular}{|c|c|c|c|c|c|c|}
\hline Strain no. & ApI (\%) & OnI (\%) & $\begin{array}{l}\text { Extracellular } \\
\text { cytotoxic activity }\end{array}$ & $\begin{array}{l}\text { Cell-contact } \\
\text { cytotoxicity }(\%)\end{array}$ & AdI $\left[\times 10^{5}\right]$ & $\overline{\operatorname{InI}(\%)}$ \\
\hline \multicolumn{7}{|c|}{ A. calcoaceticus } \\
\hline MPU M12 & $\begin{array}{l}65.1^{\mathrm{a}} / 61.2 \\
67.1^{\mathrm{b}} / 58.7\end{array}$ & $\begin{array}{l}11.6^{\mathrm{c}} / 17.8 \\
21.3^{\mathrm{d}} / 16.4\end{array}$ & $32^{\mathrm{e}}$ & $71.3^{\mathrm{f}}$ & $25.4^{\mathrm{g}}$ & $0.07^{\mathrm{h}}$ \\
\hline MPU M5 & $\begin{array}{l}61.3 / 57.1 \\
78.6 / 73.1\end{array}$ & $\begin{array}{l}8.7 / 6.8 \\
15.4 / 11.6\end{array}$ & 32 & 72.4 & 24.3 & 3.1 \\
\hline MPU M13 & $\begin{array}{l}56.3 / 37.1 \\
67.6 / 42.7\end{array}$ & $\begin{array}{l}7.9 / 6.8 \\
18.7 / 14.1\end{array}$ & 8 & 65.4 & 27.6 & 0.1 \\
\hline MPU M4 & $\begin{array}{l}56.1 / 61.4 \\
60.3 / 57.1\end{array}$ & $\begin{array}{l}11.6 / 12.8 \\
21.4 / 18.7\end{array}$ & 1 & 69.8 & 21.6 & 1.2 \\
\hline MPU M9 & $\begin{array}{l}50.7 / 29.2 \\
59.9 / 31.4\end{array}$ & $\begin{array}{l}4.8 / 3.6 \\
9.4 / 7.4\end{array}$ & 0 & 54.6 & 21.9 & 11.5 \\
\hline MPU M6 & $\begin{array}{l}43.4 / 47.6 \\
36.1 / 40.7\end{array}$ & $\begin{array}{l}50.3 / 45.6 \\
45.1 / 41.3\end{array}$ & 0 & 59.7 & 18.8 & 57.8 \\
\hline MPU M19 & $\begin{array}{l}35.4 / 38.1 \\
44.8 / 39.1\end{array}$ & $\begin{array}{l}51.4 / 54.3 \\
53.7 / 49.6\end{array}$ & 0 & 39.6 & 20.7 & 51.3 \\
\hline MPU M8 & $\begin{array}{l}18.6 / 23.2 \\
28.3 / 31.2\end{array}$ & $\begin{array}{l}49.2 / 45.7 \\
56.1 / 55.8\end{array}$ & 0 & 51.4 & 19.6 & 61.2 \\
\hline MPU M17 & $\begin{array}{l}16.1 / 18.3 \\
29.4 / 31.6\end{array}$ & $\begin{array}{l}8,5 / 4.2 \\
12.6 / 9.8\end{array}$ & 1 & 31.2 & 17.4 & 0.8 \\
\hline MPU M7 & $\begin{array}{l}14.6 / 7.8 \\
21.4 / 12.7\end{array}$ & $\begin{array}{l}51.6 / 54.7 \\
67.9 / 64.2\end{array}$ & 0 & 68.5 & 19.7 & 49.3 \\
\hline A. baumann & & & & & & \\
\hline MPU M25 & $\begin{array}{l}58.1 / 53.2 \\
65.4 / 61.7\end{array}$ & $\begin{array}{l}11.4 / 7.2 \\
18.9 / 9.7\end{array}$ & 0 & 61.3 & 23.6 & 0.08 \\
\hline MPU M20 & $\begin{array}{l}57.4 / 37.8 \\
65.7 / 39.1\end{array}$ & $\begin{array}{l}7.8 / 5.4 \\
18.5 / 14.1\end{array}$ & 8 & 64.2 & 21.4 & 0.09 \\
\hline MPU M22 & $\begin{array}{l}57.3 / 31.8 \\
68.4 / 38.7\end{array}$ & $\begin{array}{l}11.4 / 8.7 \\
21.7 / 15.3\end{array}$ & 1 & 58.6 & 23.7 & 1.8 \\
\hline MPU M21 & $\begin{array}{l}56.1 / 29.7 \\
66.8 / 49.3\end{array}$ & $\begin{array}{l}21.3 / 11.4 \\
28.3 / 21.7\end{array}$ & 4 & 57.1 & 28.5 & 2.7 \\
\hline MPU M24 & $\begin{array}{l}38.6 / 13.2 \\
54.8 / 21.7\end{array}$ & $\begin{array}{l}5.9 / 5.1 \\
12.9 / 7.8\end{array}$ & 32 & 48.3 & 23.8 & 0.6 \\
\hline MPU M23 & $\begin{array}{l}27.3 / 9.8 \\
38.7 / 19.6\end{array}$ & $\begin{array}{l}51.1 / 61.2 \\
59.7 / 68.3\end{array}$ & 1 & 61.4 & 15.7 & 52.8 \\
\hline MPU M16 & $\begin{array}{l}32.1 / 29.3 \\
34.7 / 26.8\end{array}$ & $\begin{array}{l}48.1 / 51.6 \\
57.5 / 61.2\end{array}$ & 0 & 42.1 & 19.1 & 58.1 \\
\hline
\end{tabular}

${ }^{a}$ The percentage of apoptotic cells at $24 \mathrm{~h}$ without pan-caspase inhibitor/with the inhibitor

b The percentage of apoptotic cells at $48 \mathrm{~h}$ after infection without the pan-caspase inhibitor/with the inhibitor

c The percentage of oncotic cells at $24 \mathrm{~h}$ without the pan-caspase inhibitor/with the inhibitor

${ }^{\mathrm{d}}$ The percentage of oncotic cells at $48 \mathrm{~h}$ after infection without the pan-caspase inhibitor/with the inhibitor

e The reciprocal of the highest dilution of supernatant yielding rounding, detachment and destruction of $50 \%$ of a HEp- 2 monolayer at $24 \mathrm{~h}$

${ }^{\mathrm{f}}$ The percentage of cytotoxicity was determined by MTT at $5 \mathrm{~h}$

g The mean total number of CFU associated bacteria per well

$\mathrm{h}$ The percentage of intracellular bacteria after gentamicin treatment in comparison to initial inoculum. All values correspond to the means from two experiments in triplicate 
[18] have suggested that exopolysaccharide-producing strains are more pathogenic than those non-producing ones.

\section{Cell-Contact Cytotoxicity}

The results presented in the study provided the evidence of the cell-contact cytotoxicity of Acb strains. After 3-h incubation with Acb, the cells began to round up, and a large number of them became swollen, usually detaching from the plate surface at $5 \mathrm{~h}$ (results not shown). We observed that all strains were cytotoxic, which required direct contact between epithelial cell and the bacteria. The contact with five $(50 \%)$ A. calcoaceticus and one (14\%) A. baumannii induced the highest percentage of cytotoxicity (Table 2). Incubation with bacterial cells longer than $6 \mathrm{~h}$ caused total destruction of HEp-2 monoloayer infected with seven (41\%) strains. The lowest cytotoxicity, below $40 \%$, was observed for two $(20 \%)$ A. calcoaceticus strains. No cytotoxicity was noticed when Acinetobacter spp. cells were not allowed to contact with epithelial cells in the culture inserts, which suggested that cytotoxicity is cell-contact dependent. No cell lysis was observed at 5-h incubation with culture supernatants 14 (82\%) strains, culture medium (GM), and non-pathogenic E. coli $\mathrm{K}-12$ C600 strain.

Secretion system proteins could be responsible for the cell-contact cytotoxicity. A. baumannii strains possess type II and IV secretion system proteins that transfer toxins, extracellular proteases and other enzymes from bacteria to the host cells, and contributed to the bacteria cytotoxicity and pathogenesis $[8,35]$.

Apoptosis of epithelial cells infected with Acb complex strains

Live uninfected and infected cells showed green fluorescence (Fig. 1A). In contrast, red nuclei appeared in HEp-2 cells after $24 \mathrm{~h}$ of infection with Acb strains, indicating that $\mathrm{EtBr}$ and $\mathrm{AO}$ entered the cells (Fig. 1B). The results suggested that the infection is involved in pore formation in the cell membrane, leading to the uptake of $\mathrm{EtBr}$ and osmotic lysis. The highest ApI, ranging from 56.1 to $65.1 \%$ at $24 \mathrm{~h}$ after infection, was observed in cells incubated with four $(40 \%)$ A. calcoaceticus and four (57\%) A. baumannii strains. The lowest ApI, between 18.6 and $32.1 \%$, was expressed by one $(14 \%) A$. strain and three $(30 \%)$ A. calcoaceticus strains. The percentage of apoptotic cells increased at $48 \mathrm{~h}$ post infection (Table 2). The highest ApI ranging from 67.1 to $78.8 \%$ was observed in HEp-2 cells infected with one (14\%) A. baumanii and three $(30 \%)$ A. calcoaceticus strains. The lowest index, ranging from 21.4 to $36.1 \%$, was revealed by cells infected with one (14\%) A. baumannii and four (40\%) A. calcoaceticus strains. The mean ApI of the negative control was $9.6 \pm 1.8 \%$, whereas for the UV-irradiated positive control it reached $94.6 \pm 5.1 \%$. The Pearson linear correlation test revealed positive correlation between the ApI and AdI of cells infected with Acb complex strains $(r=0.51$, $P<0.01)$. The results were confirmed by treatment of HEp-2 cells with cytochalasin D, which inhibits actin polymerization and therefore, bacterial invasion of the cells. The incubation did not inhibit cell killing by apoptosis, which suggested that bacterial invasion of epithelial cells was not responsible for the cell death. Moreover, the Pearson coefficient increased for correlations between the apoptotic index and cell-contact cytotoxicity $(r=0.73$, $P<0.01)$.

All Acb strains had low necrotic activity. Necrotic cells were characterized by their cellular swelling and orange nucleus (Fig. 1B). The necrotic indexes ranged from $4.2 \pm 1.1$ to $11.6 \pm 4.6 \%$ at $24 \mathrm{~h}$ and increased to $15.1 \pm 3.8 \%$ at $48 \mathrm{~h}$.

To gain further insight into nuclear and cytoplasmic changes of epithelial cells caused by Acb strains, we performed electron microscopy studies compared with noninfected cells (Fig. 2a). During $24 \mathrm{~h}$ after infection with
Fig. 1 Apoptosis and necrosis of infected HEp-2 cells. The cells were stained with propidium iodide and $\mathrm{AO}$ $(100 \mu \mathrm{g} / \mathrm{ml})$ and observed in the fluorescence microscope; The cells were incubated with A Eagle culture medium; B A. calcoaceticus MPU M12; the arrows pointed: $a$ live, $b$ apoptotic, $c$ necrotic cells. Magnifications: $\mathbf{A} \times 250$, B $\times 200$
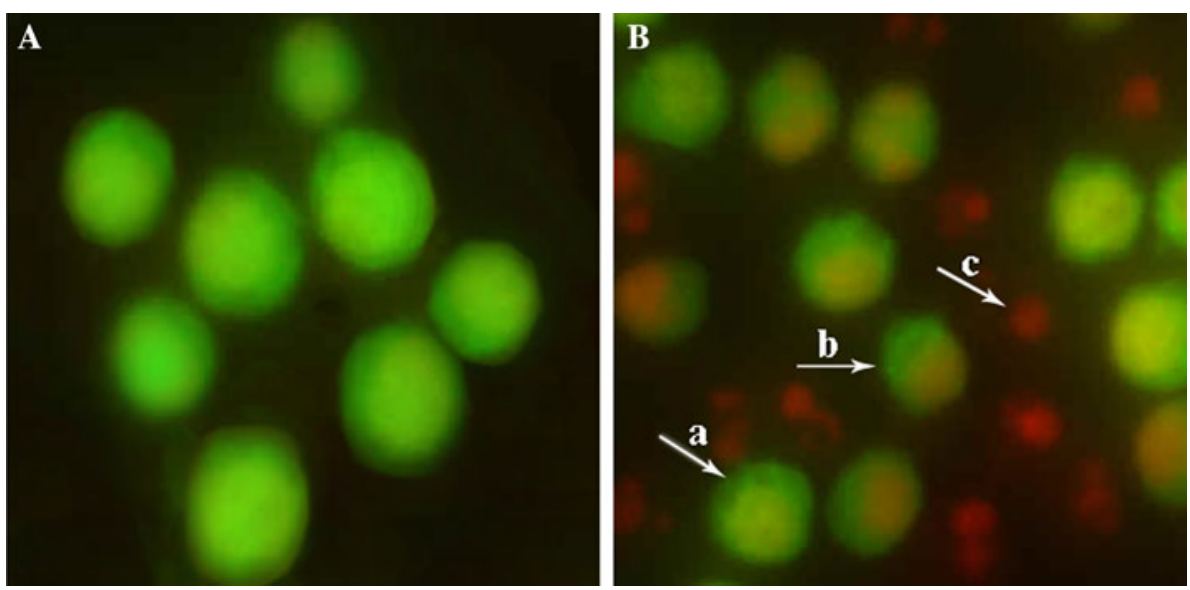

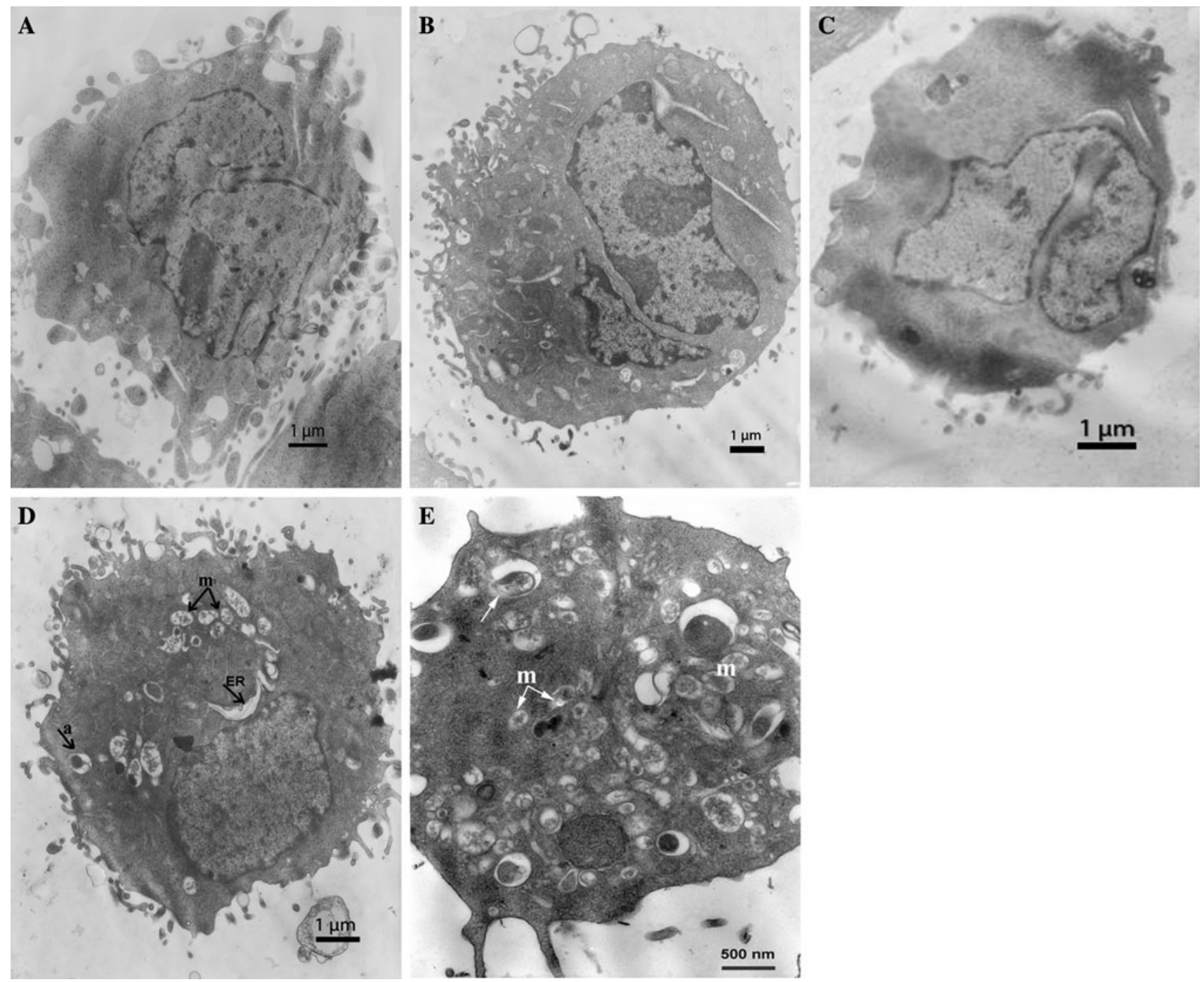

Fig. 2 Transmission electron micrographs of HEp-2 cells infected with Acinetobacter spp strains. a Control, uninfected cell do not show remarkable morphology changes after incubation in culture medium. b Chromatin condensation and margination in HEp-2 cells infected with A. calcoaceticus MPU M12 at $24 \mathrm{~h}$ after infection; c Nuclear fragmentation; d Disruption of the cytoplasmic organization by

A. calcoaceticus MPU M7 at $24 \mathrm{~h}$ after infection: note the dilation of endoplasmic reticulum $(E R)$ elements and mitochondria $(m)$, formation of autophagic vacuoles $(a)$; E. Intracellular bacteria were surrounded by a membrane-bound vacuole (arrow), vesiculation of the cytoplasmic membrane-bound organelles, swelling and dilation of mitochondria $(m)$

four A. calcoaceticus and A. baumannii strains, we observed the hallmarks of apoptosis in more than $50 \%$ of the cells: rounding-up of the cells, retraction of pseudopodes, reduction of cellular volume, condensation with margination of chromatin (Fig. 2b), and nuclear fragmentation (Fig. 2c). The results were consistent with fluorescence microscopy observations. The analysis of intranucleosomal DNA fragmentation is used to indicate cells undergoing apoptosis. We observed patterns of low-molecular-weight DNA in cells infected with four (40\%) A. calcoaceticus and four $(57 \%)$ A. baumannii strains at $24 \mathrm{~h}$, and with five A. calcoaceticus $(50 \%)$ and A. baumannii $(71 \%)$ at $48 \mathrm{~h}$ after infection. The pattern was observed in cells with ApI above $53 \pm 3.1 \%$.

The results are consistent with other studies indicating that $A$. baumannii strains induce apoptosis of epithelial cells [6, 7, 34]. Smani et al. [34] have reported that an A. baumannii strain causes cell death of lung epithelial cells involving a perturbation of cytosolic calcium homeostasis. The strain causes release of the intracellular $\mathrm{Ca}^{+2}$ from the mitochondria and endoplasmic reticulum. Choi et al. [6] have observed that purified AbOmp enters the epithelial cells localized to the mitochondria and releases proapoptotic molecules cytochrome $c$ and apoptosis-inducing factor (AIF).

We observed for the first that infection with Acb strains of HEp-2 cells lead to oncotic changes as cytoplasmic blebbing, with disruption of normal morphology (Fig. 2d). 
This included vesiculation of cytoplasmic organelles, dilation of the endoplasmic reticulum (ER) elements, and formation of autophagic vacuoles. The mitochondria from HEp-2 cells infected with the strains showed electrondense packed cristae; in some cells, the mitochondria became swollen with completely unstructured cristae and shapes consisting of vesicle-like structures with enlarged inner space and dense inclusion bodies, providing evidence that the strains induced mitochondrial changes. We assessed the percentage of oncotic cells as oncotic index (OnI) that was determined by counting a minimum of 100 cells (Table 2). The highest OnI was observed for five (50\%) A. calcoaceticus (MPU M6, 7, 8, 17, 19) and two (28\%) A. baumannii strains (MPU M16, 23) at 24 and $48 \mathrm{~h}$. Their indexes ranged from 49.2 to $51.6 \%$ and 48.1 to $67.9 \%$. The strains did not cause nuclear DNA fragmentation. Interestingly, the strains had to be located intracellularly to induce oncosis, which is evident because cytochalasin D inhibited the internalization of the bacteria and prevented cell death. The oncotic indexes were reduced to the range from 9.6 to $4.2 \%$ after treatment of the HEp-2 monolayer with cytochalasin D prior to infection. Transmission microscopic observations provided direct evidence of intracellular localization of A. calcoaceticus strains in membrane-surrounding vacuoles (Fig. 2e). Our results revealed that high invasion indexes (above $51 \%$ ), comparable to the invasive control, were consistent with the ability to induce oncosis of HEp-2 cells, showing a high level of invasion and the oncotic index. In contrast, infection with non-pathogenic E. coli K12C600 with low adhesion and invasion indexes did not trigger cell death.

Previous studies have suggested that host cell death may be associated with bacterial invasion. Kalischuk et al. [19] have presented that Campylobacter jejuni induces enterocyte oncosis, which correlates with increased invasion ability. The cell death is independent of cytolethal distending toxin expression.

\section{Loss of Mitochondrial Membrane Potential in HEp-2 Cells Infected with Acinetobacter spp. Strains}

While TEM observations manifested that the mitochondria found in epithelial cells are morphologically disrupted during Acb-infection, the functional nature of these organelles within the infected epithelium remains uncertain. Therefore, we determined the effect of the strains on mitochondrial transmembrane potential $\left(\Delta \Psi_{\mathrm{m}}\right)$. We observed that infected HEp-2 cells, in the range from $56.3 \pm 3.1$ to $89.6 \pm 4.1 \%$ exhibited a reduced level of TMRE fluorescence, compared to only $6.8 \pm 2.1 \%$ of the control ones incubated with a non-pathogenic $E$. coli strain. The number of the cells with reduced level of fluorescence increased to the range from $67.1 \pm 2.8$ to $97.3 \pm 2.1 \%$ at $48 \mathrm{~h}$ after infection. We determined the fluorescence intensity at a single cell level (Fig. 3). The average pixel intensity for each cell was assessed. We determined the membrane potential in viable, apoptotic, and oncotic cells. The fluorescence was the highest in control viable cells (Fig. 3a) in comparison with apoptotic (Fig. 3b) and oncotic ones (Fig. 3c). The control cells had mean fluorescence above 250 FU. Acinetobacter spp.-infected apoptotic cells revealed decline in TMRE fluorescence in comparison with the controls to the minimum level of $65 \pm 27 \mathrm{FU}$ at $24 \mathrm{~h}$. Interestingly, the lowest values of fluorescence intensity in the range from $51 \pm 22$ to $24 \pm 11 \mathrm{FU}$ were noticed in oncotic cells. The reduction of intensity of $\Delta \Psi_{\mathrm{m}}$-sensitive dye TMRE in Acinetobacter spp.-infected cells indicated mitochondrial depolarization. The Pearson test revealed positive correlation between the ApI and loss of $\Delta \Psi_{\mathrm{m}}(r=-0.58, P<0.01)$.

Mitochondria have been identified as the target of an increasing number of bacterial proteins, which are transferred to the cell during infection and play a crucial role in bacterial pathogenesis and modulation of host cell death $[2,32]$. Therefore, many microbial strategies are aiming at targeting these organelles to stimulate cell death pathways. Rudel et al. [32] have suggested that loss of mitochondrial functions is a feature of both apoptotic and oncotic cell death. The disruption of $\Delta \Psi_{\mathrm{m}}$ has been established to be an indicator of mitochondrial damage. A reduction in the potential is believed to be mediated by the opening of the mitochondrial pores. Under normal circumstances, most of the pores are closed, and their opening has consequences for mitochondrial physiology, including efflux of small molecules and proteins from the mitochondrium. Strains of A. baumannii induced a release of proapoptotic molecules such as cytochrome $c$ and AIF [6].

\section{Inhibition of Caspases}

In cells infected with $5(29 \%)$ strains, the treatment with the pan-caspase inhibitor resulted in the reduction of apoptotic cells by $34.2-65.8 \%$ after $24 \mathrm{~h}(P<0.01)$. The results indicated that apoptosis of epithelial cells induced by the strains could be associated with the activation of caspases. In contrast, the inhibitor did not significantly affect ApI in cells infected with 7 (64\%) strains and did not prevent Acb-induced oncosis (Table 2). The results suggested that the cell death induced by the strains is independent of known caspases.

Activation of caspases could be recognized as a key element in the apoptotic process. Smani et al. [34] have reported that lung epithelial cell apoptosis induced by A. baumannii strain involves calpain and caspase- 3 activation. However, new evidence is drawing attention to the 

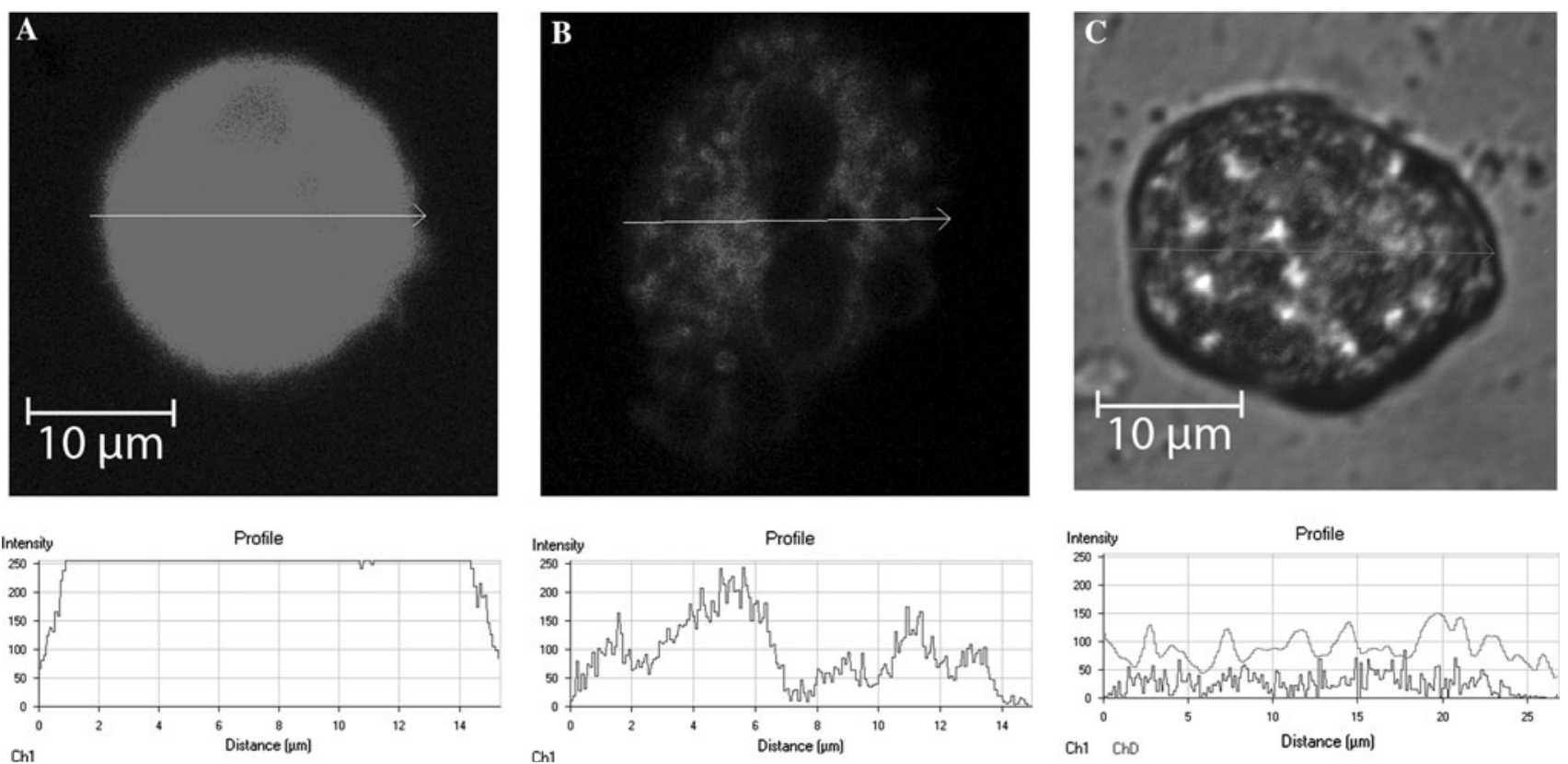

Fig. 3 Mitochondrial membrane potential of HEp-2 cells and TMRE fluorescence intensity at a single cell level after 24-h incubation with: a Eagle minimum essential medium, b A. calcoaceticus MPU M12,

c $A$. calcoaceticus MPU M7. $\Delta \Psi_{\mathrm{m}}$ was assessed after TMRE staining. The fluorescence was visualized by laser confocal microscopy

emergent role of cell death pathways, where caspases are not involved [26]. There are some other proteases (cathepsins, calpains, granzymes, and serine proteases) that induce apoptosis in the absence of caspase activity [5]. Moreover, apoptosis could be activated by mitochondrial changes that do not require caspases. One of distinct pathways from the mitochondria is the release of the AIF from the intermembrane space. AIF induces caspase-independent formation of large $(50 \mathrm{~kb})$ chromatin fragments. Choi et al. [6] have suggested that outer membrane protein 38 (omp38) affects the mitochondria and releases proapoptotic molecules such as cytochrome $c$ and AIF. Another mitochondrial protein that contributes to caspase-independent cell death is endonuclease $\mathrm{G}$ that induces DNA fragmentation in nuclei $[5]$.

Acinetobacter spp.-induced NO production in epithelial cells

We tried to define the mechanisms leading to loss of mitochondrial integrity. We observed that the infection induced a significant increase in the level of intracellular $\mathrm{NO}$ in epithelial cells. All strains produced increased levels of NO, significantly higher than that of the non-pathogenic control $(1.1 \pm 0.6 \mu \mathrm{M}$ at $24 \mathrm{~h}, 1.5 \pm 0.3 \mu \mathrm{M}$ at $48 \mathrm{~h})$. The highest NO production, 17.3-25.8 $\mu \mathrm{M}$, was detected in cell supernatants infected with four $(40 \%)$ A. calcoaceticus (MPU M19, 8, 7, 6) strains and two (28\%) A. baumannii
(MPU M16, 23) at 24, the concentrations decreased to $11.7-19.2 \mu \mathrm{M}$ at $48 \mathrm{~h}$ for the strains. Moreover, we observed positive correlation between the apoptotic index and NO production $(r=0.73, P<0.01)$.

The incubation of infected cells with aminoguanidine reduced the number of the dead cells with low TMRE fluorescence to the range from 26 to $41 \%$, suggesting that NO induced depolarization of the mitochondrial membrane. Treatment with tocopherol significantly inhibited Acb-induced ROS production and increased $\Delta \Psi_{\mathrm{m}}$ levels nearly as the control cells. The mean percentage of the cells with a reduced level of TMRE fluorescence decreased to $12.6 \pm 4.1(P<0.01)$, suggesting that the loss of mitochondrial membrane potential was a consequence of oxidative stress.

Host cells death can be induced by endogenous second messengers, which are elicited in response to stress. NO is one of the factors that can trigger apoptosis [9]. However, NO involvement in the cell death induced by Acb has not yet been characterized. We observed that most $(83 \%)$ of the strains that induced the highest level of NO were isolated from urine. It has been observed that the increased concentration of free radicals in infected kidneys plays a role in the injury of renal cortical cells in uropathogenic E. coli infections [16]. NO can stimulate mitochondrial production of ROS, like superoxide, hydrogen peroxide, peroxynitrite, which all have proapoptotic potential. NO alone could also inhibits mitochondrial respiration, and 
reacts with ROS to form the particularly cytotoxic species peroxinitrite [11]. Smani et al. [34] have reported that infection of lung epithelial cells with A. baumannii strain induces ROS generation that leads to the cell death.

\section{Conclusions}

Induction of host cell death is thought to play an important role in bacterial pathogenesis [25]. In the study, we provided evidence that Acb complex strains induce apoptosis of epithelial cells from an extracellular location, through adhesion to the cells and cell contact-mediated cytotoxicity. Moreover, for some strains, bacterial cell contact of epithelial cells and invasion was required for Acb-induced cytotoxicity and cell death by oncosis. The results suggested that activation of different cell death pathways in epithelial cells could constitute an important pathogenic mechanism by which the strains evade host immune defence and cause disease. The results provide new insights into the pathogenesis of Acb complex infections.

Open Access This article is distributed under the terms of the Creative Commons Attribution License which permits any use, distribution, and reproduction in any medium, provided the original author(s) and the source are credited.

\section{References}

1. Antigny F, Girardin N, Raveau D, Frieden M, Becq F (2009) Dysfunction of mitochondria $\mathrm{Ca}^{2+}$ uptake in cystic fibrosis airway epithelial cells. Mitochondrion 9:232-241

2. Arnoult D, Carneiro L, Tattoti I, Giardin SE (2009) The role of mitochondria in cellular defense against microbial infection. Semin Immunol 21:223-232

3. Borutaite V, Brown G (2005) What else has to happen for nitric oxide to induce cell death? Biochem Soc Trans 33:1394-1396

4. Bouchier-Hayes L, Muñoz-Pinedo C, Connell S, Green DR (2008) Measuring apoptosis at single cell level. Methods 44: 222-228

5. Bröker LE, Kruyt FAE, Giaccone G (2005) Cell death independent of caspases: a rewiev. Clin Cancer Res 11:3155-3162

6. Choi CH, Lee EY, Lee YC, Park TI, Kim HJ, Hyun SH, Kim SA, Lee S-K, Lee JC (2005) Outer membrane protein 38 of Acinetobacter baumannii localizes to the mitochondria and induces apoptosis of epithelial cells. Cell Microbiol 7:1127-1138

7. Choi CH, Lee JS, Lee JC, Park TI, Lee JC (2008) Acinetobacter baumannii invades epithelial cells and outer membrane protein $\mathrm{A}$ mediates interaction with epithelial cells. BMC Microbiol 8: 216-227

8. Cianciotto NP (2005) Type II secretion: a protein secretion system for all seasons. Trends Microbiol 13:581-588

9. Circu ML, Aw TY (2010) Reactive oxygen species, cellular redox systems, and apoptosis. Free Radic Biol Med 48:749-762

10. Curtin JF, Donovan M, Cotter TG (2002) Regulation and measurement of oxidative stress in apoptosis. J Immunol Meth 265: $49-72$
11. Fink SL, Cookson BT (2005) Apoptosis, pyroptosis and necrosis: mechanistic description of dead and dying eucaryotic cells. Infect Immun 73:1907-1916

12. Gladstone P, Jesudason MV, Sridharan G (2003) Invasive properties of South Indian strains of Streptococcus pyogenes in a HEp-2 cell model. Clin Microbiol Infect 9:1031-1034

13. Gohl O, Friedrich A, Hoppert M, Averhoff B (2006) The thin pili of Acinetobacter sp. strain BD413 mediated adhesion to biotic and abiotic surfaces. Appl Environ Microbiol 72:13941401

14. Henwood CJ, Gatward T, Warner M, James D, Stockdale MW, Spence RP, Towner KJ, Livermore DM, Woodford N (2002) Antibiotic resistance among clinical isolates of Acinetobacter in the UK, and in vitro evaluation of tigecycline (GAR-936). J Antimicrob Chemother 49:479-487

15. Jacobs AC, Hood I, Boyd KL, Olson PD, Morrison JM, Carson S, Sayood K, Iwen PC, Skaar EP, Dunman PM (2010) Inactivation of phospholipase D diminishes Acinetobacter baumannii pathogenesis. Infect Immun 78:1952-1962

16. Jahnukainen T, Chen M, Celsi G (2005) Mechanisms of renal damage owing to infection. Pediatr Nephrol 20:1043-1053

17. Jin JS, Kwon S-O, Moon DC, Gurung M, Lee JH, Kim S, Lee JC (2011) Acinetobacter baumannii secretes cytotoxic outer membrane protein A via outer membrane vesicles. PloS One 6(2): e17027

18. Joly-Guillou M-L (2005) Clinical impact and pathogenicity of Acinetobacter. Clin Microbiol Infect 11:868-873

19. Kalischuk LD, Inglis GD, Buret AG (2007) Strain dependent induction of epithelial cell oncosis by Campylobacter jejuni is correlated with invasion ability and is independent of cytolethal distending toxin. Microbiol 153:2952-2963

20. Krzymińska S, Mokracka J, Koczura R, Kaznowski A (2009) Cytotoxic activity of Enterobacter cloacae human isolates. FEMS Immunol Med Microbiol 56:248-252

21. Krzymińska S, Koczura R, Mokracka J, Puton T, Kaznowski A (2010) Isolates of the Enterobacter cloacae complex induce apoptosis of human intestinal epithelial cells. Microb Pathog 49: 83-89

22. Krzymińska S, Mokracka J, Koczura R, Ćwiertnia A, Kaznowski A (2012) Aeromonas spp.-mediated cell-contact cytotoxicity is associated with the presence of type III secretion system. Antonie Van Leeuwenhoek 101:234-251

23. Kurcik-Trajkovska B (2009) Acinetobacter spp.-a serious enemy threatening hospital worldwide. Maced J Med Sci 15:157-162

24. Labbé K, Saleh M (2008) Cell death in the host response to infection. Cell Death Differ 15:1339-1349

25. Lin CF, Chen CL, Huang WC, Cheng YL, Hsieh CY, Wang CY, Hong MY (2010) Different types of cell death induced by enterotoxins. Toxins 2:2158-2176

26. Lorenzo HK, Susin SA (2004) Mitochondrial effectors in caspase-independent cell death. FEBS Lett 557:14-20

27. Majno G, Joris I (1995) Apoptosis, oncosis and necrosis: an overview of cell death. Am J Pathol 146:3-15

28. Niemann HH, Schubert W-D, Heinz DW (2004) Adhesins and invasins of pathogenic bacteria: a structural view. Microbes Infect 6:101-112

29. Nilsson BO (1999) Biological effects of aminoguanidine: an update. Inflamm Res 48:509-515

30. Peleg AY, Seifert H, Paterson DL (2008) Acinetobacter baumannii: emergence of a successful pathogen. Clin Microbiol Rev 21:538-582

31. Ribble D, Goldstein NB, Norris DA, Shellman YG (2005) A simple technique for quantifying apoptosis in 96-well plates. BMC Biotechnol 5:12 
32. Rudel T, Kepp O, Kozjak-Pavlovic V (2010) Interactions between bacterial pathogens and mitochondrial cell death pathways. Nature Microbiol Rev 8:695-705

33. Sebeny PJ, Riddle MS, Petersen K (2008) Acinetobacter baumannii skin and soft-tissue infection associated with was trauma. Clin Infect Dis 47:444-449

34. Smani Y, Docobo-Perez F, McConnell MJ, Pachon J (2011) Acinetobacter baumannii-induced lung cell death: role of inflammation, oxidative stress and cytosolic calcium. Microb Pathog 50:224-232

35. Smith MG, Gianoulis TA, Pukatzki S, Mekalanos JJ, Ornston LN, Gerstein M, Snyder M (2007) New insights into Acinetobacter baumannii pathogenesis revealed by high-density pyrosequencing and transposon mutagenesis. Genes Dev 21:601-614

36. Trump BF, Berezesky IK, Chang SH, Phelps PC (1997) The pathways of cell death: oncosis, apoptosis, and necrosis. Toxicol Pathol 25:82-88

37. Yu Y-S, Yang Q, Xu X-W, Kong H-S, Xu G-Y, Zhong B-Y (2004) Typing and characterization of carbapenem-resistant Acinetobacter calcoaceticus-baumannii complex in a Chinese hospital. J Med Microbiol 53:653-656 